\title{
The Impact of US Aid on the Attitudes of Educated Youth of Pakistan
}

\author{
Musarrat Shamshir \\ Faculty of Management Sciences, Greenwich University \\ DK-10, 38 Street, Darakshan, Phase VI, DHA, Karachi-75500, Pakistan \\ Saira Saleem \\ Department of Special Education, University of Karachi, Pakistan \\ Shahida Sajjad \\ Faculty of Social Sciences and Humanities, Greenwich University \\ DK-10, 38 Street, Darakshan, Phase VI, DHA, Karachi-75500, Pakistan \\ Kim Guam \\ Faculty of Social Sciences and Humanities, Greenwich University \\ DK-10, 38 Street, Darakshan, Phase VI, DHA, Karachi-75500, Pakistan
}

\begin{abstract}
Pakistan is one of the countries which have been economically well aided by the US for a long time. A survey conducted in 2012 by Pew Research Center's on the Pakistani people's attitude towards the US, reveals that majority of the Pakistanis have antipathies against US. This research aimed to explore the opinions of Pakistani educated youth about the significance of US economic aid for Pakistan and the extent of their likeness for the residents of US and its policies towards region, specifically towards Pakistan especially after the incidence of 9/11. The data was collected with the help of a structured questionnaire by interviewing 300 university students over 18 years of age from various public and private sector universities in Karachi. This research shows that most of the respondents of the survey answered the US economic aid to their country is significant and helpful, differently from the result of the above Pew Research Center's 2012 survey. Furthermore, half of them showed their likeness towards people of US and their policies to support Pakistan in alleviating poverty and for the economic development of their country. This situation shows that the young and well educated generation has more positive attitudes towards the US than the general population in Pakistan. Nonetheless, more than half of the respondents considered the reason the US has increased its economic aid to their country since $9 / 11$ is not for Pakistan but for its engagement in 'counter-terrorism in Afghanistan'. The study concludes the signs of correlation between the US aid to Pakistan and likeness of Pakistani youth towards the people of US. This result has the important implication on the future relationship between US and Pakistan.
\end{abstract}

DOI: $10.7176 / \mathrm{DCS} / 9-4-11$

Publication date: April $30^{\text {th }} 2019$

\section{Introduction}

In the words of Zinkin (1978, pp 22), "Aid is charity, if it is not charity, it is not aid". Similarly another quote, "foreign aid has become one of the America's most important techniques of statecraft" (see Baldwin, 1966, pp 66). There have been general public antipathies against the USA among the countries which have been taking the aids from it. It is interesting phenomena that the beneficiaries have the antagonism to their supporter. This research tries to show whether the educated youth generally have the positive or negative feelings toward the US aids to their country especially since 9/11 when the US has sharply increased its economic and military aid to Pakistan. This research is aimed to investigate: i) the significance of the USA economic aid for Pakistan as perceived by the educated youth; ii) the correlation between USA economic aid and attitude of the youth towards it; iii) the correlation between USA economic aid and attitude of young students toward people of US, the policies and its preference as a country; iv) the implications of Pakistani educated youth' attitude on Pakistan and US relations.

This research collected data to explain the annual US aid to Pakistan and also responses from the Pakistani students at university level using questionnaires. If lots of students dislike US, its residents and policies, it may be interpreted that that US approach with the economic aid to Pakistan has been going to the opposite side of the young and educated Pakistanis' wishes.

This study cited the results of the Pew Research Center's 2012 survey on the Pakistani people's attitude towards the USA and compared its findings with that. This study shows inconsistent results with the Pew Research Center's 2012 survey on the evaluation of the US aid to Pakistan, showing the changing behaviour of the youth over the last six years and is expected to develop improved relationship between Pakistan and America. 
Another possible reason for the contradictory result might be the limitation of the study to one city. But the significance of the study is reflected by the fact that Karachi is a metropolitan city represents almost $20 \%$ of the total population. However, there would be a need to conduct a much broader survey to see the public opinion of the youth of Pakistan towards the US aid to their country.

\section{Literature Review}

Empirical studies reveal diversified evidence about the behaviour of donor and recipient country. Evidence can be found where developed countries donate poor countries to keep their supremacy on the poor country and find a way to get indulged in sovereignty of the nation, and consider aid as one of the foreign policy tool while other case reveal that developed nations on humanitarian grounds help other poor nations in their process of development. However, the result of the study conducted by Schraeder, Hook \& Taylor (1988) contradicts that theoretical statement of considering foreign aid as an strategic tool of the foreign policy. Sweden- known to be the "darling of the Third World, because of its policies of reimbursing loans on favourable terms of the recipient country. Similarly, there was time when education sector received development finances from the international donors in many developing countries (Tilak, 1988). The aid was beneficial for the development of education. Similarly OPEC countries played the role of Robin Hood and were a very major donor of development funds for many non-oil third world countries during seventies (Williams, 1976).

This study includes the survey results issued on 2012 by "Pew Research Center". The 2012 survey of Pew Research Center showed that Pakistani public opinion toward the USA was critically negative at that time. Nearly three fourths of the respondents called the USA as an enemy at that time (Pew Research Center, 2012). Almost six years has passed since Pew Research Center conducted the survey on the Pakistani public opinion toward the USA. The research is designed to find any variations in the public opinion towards the USAID have occurred, with that of 2012 survey by Pew Research Center.

Pakistan was enlisted among the top five countries which had been strongly supported by the USA from its birth till 2012. Nonetheless, the public opinion of Pakistan towards the USA was critically negative and regarded it as enemy (Pew Research Center, 2012).

\section{Methodology}

The study uses the data collected after conducting survey on 300 students of universities (both in private and public sectors) of Karachi using a questionnaire for seeking the opinion on the US aid to Pakistan and level of their liking towards US. Some facts of $9 / 11$ and the situation of the USA's increasing aids to Pakistan since that incident was incorporated in the questionnaire for the students to present a clear picture of the assistance that US is providing to Pakistan over the last 20 years.

\section{Discussion and Results}

\subsection{Evaluation on the USA Aid to Pakistan}

The USA began to provide economic and military assistance to Pakistan since 1947 when Pakistan was came into being. Pakistan is among the top five countries to receive the US economic assistance out of a total of 200 countries and regions from 1946-2012. In this situation, according to, Survey by Pew Research Center, 2012 , little more than one in ten $(12 \%)$ of the respondents believe that US economic aid had positive impact on their country (Pew Research Center, 2012).

This research exhibits that nearly three fourths (74\%) of the students at various universities considered the USA economic aid to their country as important and about four fifths of them considered US aid to their country as very helpful. Little more than one tenths of the students in Pew Research Center thought that the USA economic aid to their country is not important. In conclusion, the students of five large universities are largely satisfied with the US economic aid to their country, contrary with the results by survey by Pew Research Center, 2012.

Nonetheless, the students' responses showed the narrow gap between their satisfaction with current US aid and the need of continuous assistance to Pakistan. Regarding the question whether the US aid to their country is continuously needed or not, more than three fifths of the students answered that the US aid is needed continuously. Nearly one sixths of them denied answering and another one sixths considered that the US aid to their country is not needed any more.

\subsection{The reasons US assists Pakistan as speculated in the survey}

In this survey, the respondents were asked about their opinion to select on the basis of; between the two; economic or geographical grounds, US is interested to assist and Pakistan is important to US. About $60 \%$ of the respondents answered were convinced for the geographical and geopolitical conditions of Pakistan, US takes interest in the helm of affairs in Pakistan and the political and economic condition of Pakistan is important to US. Among 50 respondents, $14 \%$ denied answering this question. This shows that Pakistan is important for the US 
for many a reasons.

\subsection{Opinion about the USA aid to Pakistan since 9/11}

The amount of the US aid to Pakistan has fluctuated according to the relation between two countries and the events happened domestically and internationally in addition with the relationship of Pakistan with other countries as depicted in figure 1. Although the US aid to Pakistan is not continuous throughout and the sudden increase in amount since $9 / 11$ is notable. Pakistan received a total of $\$ 25.91$ billion from the US in terms of military and economic aid from 9/11, 2001 to 2013 (Mubashir, 2013).

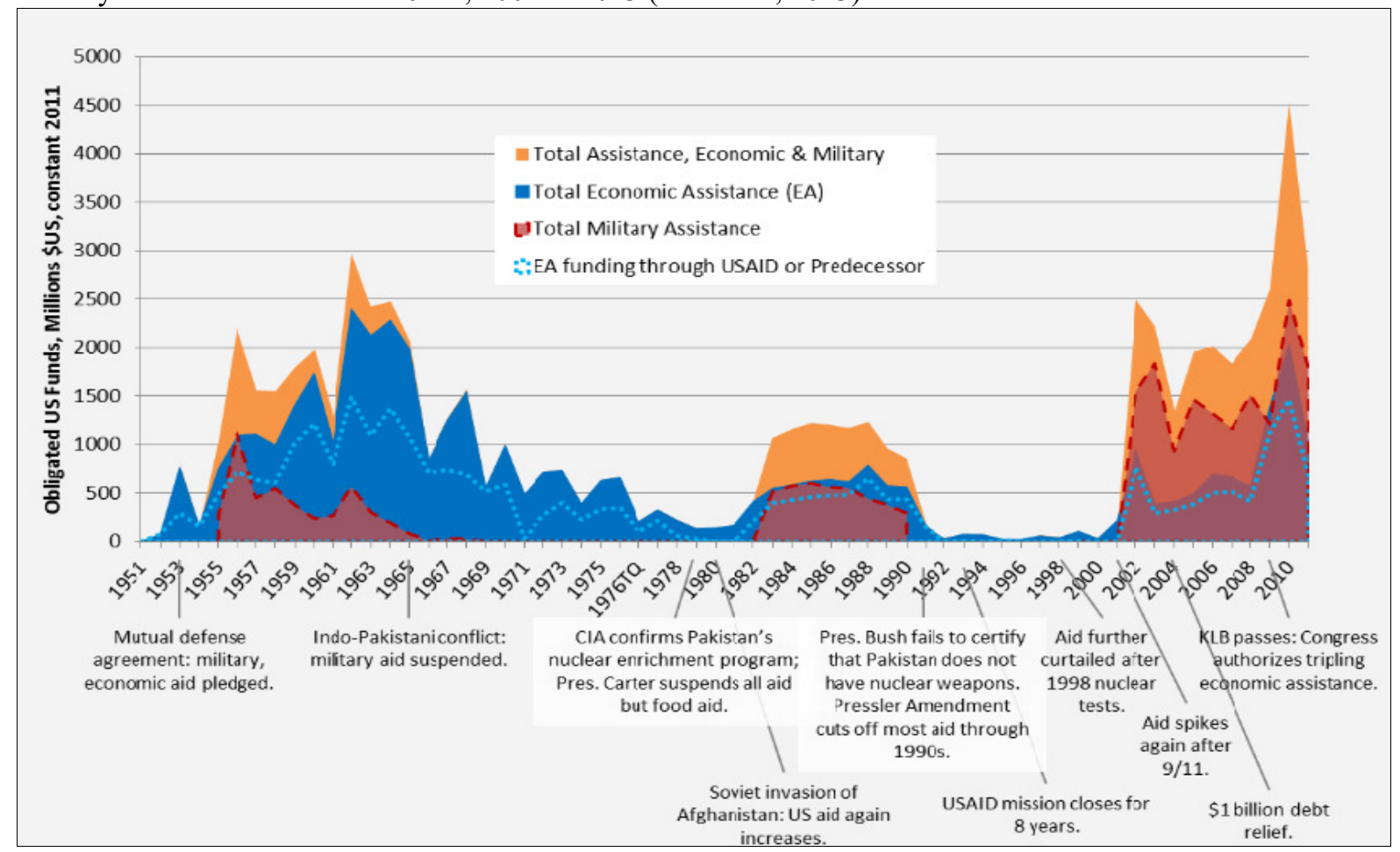

Figure 2.History of US Obligations to Pakistan, millions US\$(2011) (“Aid”, n.d.)

More than half $(60 \%)$ of the respondents convinced for the reason the US has increased its financial aid to Pakistan since 9/11 is to enhance the footstep to engage in the war on the terror in Afghanistan.

Less than half (44\%) of the respondents considered that the aid to their country has been concentrated on the military assistance since $9 / 11$. Almost one in four $(26 \%)$ of the students answered that the US aid to their country has been concentrated for the purpose of Public welfare (including educational and medical fields). Little more than one fifths $(22 \%)$ of the respondents considered that the US aid to their country has been concentrated for the economic growth of the country.

The results of the study are consistent with the prevalence of the US aid to Pakistan since 9/11. Between 2002 and 2009, only less than one thirds (30\%) of the US assistance to Pakistan was appropriated for economicrelated needs; the rest (70\%) was allocated to security-related assistance ("Aid", n.d.). "Aid" (n.d.) also shows that in between 2010-2014, little more than two fifths (41\%) of the US assistance to Pakistan has been allocated for economic-related assistance ("Aid", n.d.).

\subsection{Evaluation for the Future form of the US aid}

Exactly half of the respondents suggested that the US aid to Pakistan if continued in the future should be concentrated towards welfare and combating poverty. Nearly one in four youth surveyed (24\%) emphasized the need of aid for military assistance for meeting the requirements of the war on terror in the country. However, about $20 \%$ considered the future aid should be concentrated to achieve economic growth in the country. This results show that majority of the educated youth emphasized the targets of poverty, growth to be achieved if the aid is continued in the future.

\subsection{Extent of the likeness to the US}

Among the respondents, exactly half of the students showed their likeness for US, its residents and policies of assisting Pakistan over the last 20 years. Almost one fourth $(26 \%)$ denied responding to the specific question. One in five $(20 \%)$ of the educated youth answered that they don't like US and its policies but are indifferent about the residents. This result shows that the ratio of the preference and likeness towards America and 
Americans and their support policies for Pakistan by the educated youth of a cosmopolitan city of Pakistan is higher than of the general Pakistani people surveyed on 2012 by Pew Research Center. If the time difference of two surveys is ignored, this result implicates that young and high qualified Pakistani generation has more positive feelings towards the US, its support policies and residents than general people.

\section{Conclusion}

The majorities $(74 \%)$ of the educated youth regarded the US economic aid to their country as important and helpful. This result contradicts the result of survey conducted by Pew Research Center, 2012.

The half of the respondents considered that US has an interest in the economic and political stability of Pakistan owing to its geographical and geopolitical existence in the region. This research didn't pursue the answer what kinds of economic importance Pakistan has for the US's interest. But if any research on this case would be conducted, it would be helpful to develop the effective plan of the US economic aid to Pakistan for mutual interest.

More than three fifths of the educated youth surveyed consider an increased US aid to Pakistan is important owing to the fact the country is engaged in war against terror since the incident of $9 / 11$ in US. The youth also reflects their thoughts that the reason US has increased its aid for its own interest rather than for the military assistance of the country for the peace in the country itself. Furthermore, the youth revealed that the continuity of the US aid to Pakistan, especially for the alleviation of poverty and economic growth is crucial and should not be stopped on account Pakistan's relationship with other countries and other geopolitical changes in the region

This research showed that exactly half of the educated youth surveyed showed their likeness towards US, its residents and policy of assisting Pakistan. The ratio of the respondents' preference to the US sharply increased, in comparison with the 2012 survey conducted by Pew Research Center.

The research produces an evidence of nearly half of the youth of Pakistan having the unfavourable attitudes towards US citizens, the policies and has doubts on the objectives of aid to Pakistan. It is recommended that to enhance a positive relationship between two countries, there is a dire of building an environment of trust between the two countries. The US should take an initiative in this respect as to how to satisfy the youth of Pakistan to develop a long run relationship based on mutual interest and trust.

\section{References}

Aid to Pakistan by the Numbers.(n.d.). Retrieved from http://www.cgdev.org/page/aid-pakistan-numbers.

Baldwin, David A., (1966). Analytical Notes on Foreign Aid and Politics, Background, 10 (1), 66-90.

India biggest recipient of US economic assistance over 66-year period: USAID. (2015, July 14). DAWN. Retrieved from http://www.dawn.com/news/1194228

Mubashir, H. (2013, June27). Pakistan 'received \$25.91b' from US since 9/11. The Nation. Retrieved from http://nation.com.pk/national/27-Jun-2013/pakistan-received-25-91b-from-us-since-9-11

Pew Research Center.(2012, June 27). Pakistani Public Opinion Ever More Critical of U.S. Retrieved from http://www.pewglobal.org/2012/06/27/pakistani-public-opinion-ever-more-critical-of-u-s/

Schraeder, Peter J., Hook, Steven N., \& Taylor, Bruce (1988). Clarifying the Foreign Aid Puzzle A Comparison of American, Japanese, French and Swedish Aid Flows, World Politics, 50 (2), $294-323$.

TILAK, JANDHYALA B. G., (1988). FOREIGN AID FOR EDUCATION, INTERNATIONAL REVIEW OF EDUCATION, 34(3), 311-335.

Williams, Maurice J., (1976). The Aid Programs of the OPEC Countries, Foreign Policy, Published by Council of Foreign Relations.

Zinkin, Maurice, (1978). Aid and Morals. Addressing the Aspirations of the Poor Countries, The Round Table Journal of International Affairs, 68 (271), 222-228.




3) Moderates

4) Not very helpful

5) Not at all helpful

3. What extents do you like or dislike the USA as a country?

1) Very favorable

2) Somewhat favorable

3) Moderates

4) Somewhat unfavorable

5) Very unfavorable

4. If you think that Pakistan is important to the USA, what do you think is the main reason of it?

1) Geopolitical reason

2) Economic reason

3) None in the above

5. The USA has increased its amount of financial aids to Pakistan since $9 / 11$. What do you think has been the main reason for the USA to have increased its aids to Pakistan since 9/11?(please, select only one answer)

9/11 :It was a series of four coordinated terrorist attacks by the al-Qaeda on the United States on the morning of September 11, 2001. The attacks killed 2,996 people and injured over 6,000 others.

1) To enhance the footstep to engage in 'The War on the Terror' in the Afghanistan

2) Only because Pakistan has been the ally of the USA

3) To restrain the influence of Iran in Pakistan

4) To restrain the influence of China in Pakistan

5) None in the above

6. On which field do you think the USA's aid to Pakistan has been concentrated since 9/11

1) Military

2) Public welfare (including educational and medical fields)

3) Economy

4) None in the above

7. How do you think whether the USA's aid to Pakistan is continuously needed or not?

1) Strongly needed

2) Needed

3) Moderates

4) Unneeded

5) Strongly unneeded

8. If you think that the USA's aid to Pakistan is continuously needed, on which fields the USA's aid should be concentrated on Pakistan?

1) Military

2) Public welfare (including educational and medical fields)

3) Economy

4) None in the above

9. Please answer if you have a very favorable, somewhat favorable, somewhat unfavorable or very unfavorable opinion of the USA.

1) Very favorable

2) Somewhat favorable

3) Neutral

4) Somewhat unfavorable

5) Very unfavorable 